\title{
Effects of trace metals on infaunal species composition in polluted intertidal and subtidal marine sediments near a lead smelter, Spencer Gulf, South Australia
}

\author{
Trevor J. Ward ${ }^{1, *}$, Patricia A. Hutchings ${ }^{2}$ \\ ${ }^{1}$ CSIRO Division of Fisheries, PO Box 20, North Beach, 6020 Western Australia, Australia \\ ${ }^{2}$ Australian Museum, 6 College Street, Sydney, 2000 New South Wales, Australia
}

\begin{abstract}
The infauna of intertidal and subtidal marine sediments at 18 sites near a large lead-zinc smelter in Spencer Gulf, South Australia, was sampled twice about 6 mo apart. The sampled habitats were bare intertidal mudflats, intertidal seagrass (Zostera $5 p$.) beds, subtidal seagrass (Posidonia spp.) beds, and unvegetated sediments at 5 to $10 \mathrm{~m}$ depth. The infauna consisted of 372 identifiable taxa, mainly polychaetes, molluscs and crustaceans. The number of taxa at each site and time showed no simple relationship with the concentrations of trace metals in sediments, habitat type or time of sampling. However, the patterns of distribution, analysed using frequencies of occurrence of taxa derived from multivariate classification and ordination techniques, were related to the sediment concentrations of $\mathrm{As}, \mathrm{Cu}, \mathrm{Mn}, \mathrm{Pb}, \mathrm{Sb}$ and $\mathrm{Zn}$. The extremely high concentrations of these trace elements (probably mainly $\mathrm{Pb}$ and $\mathrm{Zn}$ ) appeared to affect both the abundances and distribution of many infaunal species. The multivariate techniques could detect which species were affected in the most metal-polluted sites (the intertidal sites). However, in the less-polluted subtidal sites, patterns in species composition were detected but only a few individual species could be unambiguously correlated to the presence of the metals. The polluted intertidal sediments, which had some of the highest metal concentrations ever recorded in marine sediments ( $\mathrm{Pb}$ up to $5270 \mu \mathrm{g} \mathrm{g}^{-1}$ and $\mathrm{Zn}$ up to $16700 \mu \mathrm{g} \mathrm{g}^{-1}$ ), supported 42 taxa. The polychaetes Heteromastus filiformis, Capitella 'capitata' and Glycera americana, and the crustacean Tanais dulongii were very abundant in these sites; they apparently can selectively exploit the metalcontaminated conditions. C. 'capitata' and $T$ dulongii were found almost exclusively in these sites. In contrast, 15 sprcics of polychaetes, 5 crustaceans and 4 molluscs found elsewhere in the study area, represcnting 26,20 , and $17 \%$ of these intertidal taxa respectively, were not found in the metal-polluted sites. No taxonomic selectivity in the effects of the metals was detected amongst the 3 major groupspolychaetes, molluscs and crustaceans. Future studies may, therefore, be able to sample indicator species from only one of these major groups to determine the spatial extent of ecological effects or to monitor metal effects in this area.
\end{abstract}

KEY WORDS: Metals - Infauna Species composition Biological effects Monitoring Smelter

\section{INTRODUCTION}

Cadmium, lead and zinc have a range of toxic effects on marine fauna, most of which were discovered by cxperimental tovicity testing in the laboratory and in the field (Langston 1990) This information is used for

·E-mail: trevor.ward@per.ml.csiro.au environmental management, particularly to predict the ecological effects on the marine environment of metals released by existing and proposed coastal developments such as smelters and mines. Indeed, envirnnmental quality criteria such as water quality guidelines (ANZECC 1992) are typically based on precepts derived from testing for acute toxicity, particularly the short-term and direct effects. 
However, information on acute toxicity is not necessarily useful for predicting the effects of trace metals on fauna that live in sediments (Somerfield et al. 1994) In most marine systems, and particularly shallow coastal systems with tight benthic-pelagic coupling, trace metals are likely to have a complex mixture of direct and indirect effects, including effects propagated through the food web and sublethal effects on reproduction or recruitment. Laboratory studies cannot fully reveal such effects, and only very detailed field studies can reveal the long-term indirect effects. However, even these cannot prove causality, because most are surveys and not experiments. They lack the normal hypothesis-testing frameworks (replicated impact sites, true control sites, etc.), and instead infer causality by correlating observations of stress and response. Correlation may not be a robust basis for environmental management if it is based on one species alone, or at one locality. It is likely to be more useful if the correlations are based on many species, particularly on species from a variety of taxa and feeding categories, and on samples from different times and different spatial scales. Studies that have used this approach found detailed patterns of association between polluted sediments and the abundances of benthic fauna (Ward \& Young 1982, Gray et al. 1990, Somerfield et al. 1994). These patterns were detected by multivariate pattern analysis of abundance data from assemblages of many species with different natural histories and feeding types.

Typically, surveys of benthic infauna, at practical levels of sampling intensity, find that few species are present in sufficient numbers to allow use of inferential statistics for testing hypotheses about abundances or spatial distributions (e.g. see Hutchings \& Jacoby 1994). The analysis of data sets using the abundances of the majority of species is highly desirable to demonstrate robust associations between faunal patterns and environmental attributes such as metals, sediment particle-size, depth and vegetation type. However, for most data sets this is only achievable with multivariate statistical techniques that are free from restrictive assumptions about underlying distributions, but can reveal general patterns about the species distributions. Species with high abundances may be susceptible to parametric statistical analysis, but the information contained in the distribution patterns of the species with lower abundances may also be important. For example, to assess the effects of pollutants on the biodiversity of shallow, species-rich marine waters, species of low or medium abundances must be included because they may be more responsive to the most subtle effects of pollution (Gray et al. 1990).

The concentrations of copper in sediments have been inferred to be causally related to the species com- position of infauna in Norwegian fjords (Rygg 1985a). Effects on infaunal species composition were detected at sediment concentrations ranging from 5 to 10 times above presumed background concentrations. Despite uncertainty about the definition of background concentrations (Luoma 1990, Ward \& Correll 1992) correlations can provide strong evidence to infer causality in appropriately designed and analysed field studies sampling a variety of faunal taxa

The world's largest lead-zinc smelter is at Port Pirie, South Australia, on the shores of Upper Spencer Gulf It has operated continuously since 1889 producing mainly lead, zinc, sulfuric acid, silver, gold, cadmium, copper and antimonial alloys. The regional distribution of metals in the gulf sediments indicates that the smelter is the only major source of metals in the region (Tiller et al. 1989). The only other potential sources of metals are runoff from the agricultural and grazing hinterland, and occasional shipping activilies. The smelter is effectively an isolated large point source for metals. Previous studies near Port Pirie have examined the distribution of trace metals in sediments (Ward \& Young 1981), the distribution of fish and crustaceans in seagrass beds related to the concentrations of metals in the sediments (Ward \& Young 1982), the partitioning of metals amongst sediment components (Ward et al. 1984), the distribution of the metals amongst the flora and fauna (Ward et al. 1986) and the species composition of the infaund (Hutchings et al. 1993).

In this study we examine the distribution of the infauna in a variety of shallow marine habitats near the smelter and investigate correlations between the concentrations of trace elements in the sediments and distribution patterns of the fauna. We describe the assemblages and the species that appear to be affected by the metal-polluted sediments and suggest species that could be used as biological response indicators (sensu Ward \& Jacoby 1992) for future survey and monitoring programs.

\section{METHODS AND MATERIALS}

The study area in Upper Spencer Gulf, South Australia $\left(33^{\circ} 19^{\prime} \mathrm{S}, 138^{\circ} \mathrm{E}\right)$ has been described by Ward \& Young (1981), Ward et al. (1984) and Hutchings et al. (1993). In brief, Spencer Gulf is a large (300 km long) generally shallow oligotrophic gulf with no rivers flowing into it (Fig. 1). The waters of the gulf are progressively more saline reaching more than $60 \mathrm{~g} \mathrm{~kg}^{-1}$ at the head. In the study area salinities typically exceed $40 \mathrm{~g}$ $\mathrm{kg}^{-1}$ for most of the year, and water temperatures typically range between a winter minimum of about $10^{\circ} \mathrm{C}$ and a summer maximum of about $28^{\circ} \mathrm{C}$. The shores of the gulf are fringed by mangroves (Avicennia marina). 
There are extensive intertidal mudflats that result from the interaction of the generally flat topography in the region with the $3 \mathrm{~m}$ tidal range in the study area. The subtidal areas are dominated by seagrass (Posidonia spp.) beds, which in places grow down to about $10 \mathrm{~m}$ depth. The sediments of deeper waters are mainly coarse carbonate sands, with finer sediments found only in the intertidal areas and the mangrove-lined fringes.

Samples of the infauna were collected from the main intertidal and subtidal habitats (other than the mangroves) in winter 1979 and summer 1980. The sampling design is described in Hutchings et al. (1993). Briefly, the infauna was sampled with $22 \mathrm{~cm}$ diam. diver-held corers to a sediment depth of about $15 \mathrm{~cm}$, and retained on $2 \mathrm{~mm}$ mesh stainless steel sieves. Generally 9 replicates, separated by about 2 to $5 \mathrm{~m}$, were collected at each site. Sites within each habitat were on a known gradient of sediment metal concentrations, along 3 transects about $8 \mathrm{~km}$ apart (Fig. 1). The habitat types, from highest to lowest elevation, were bare

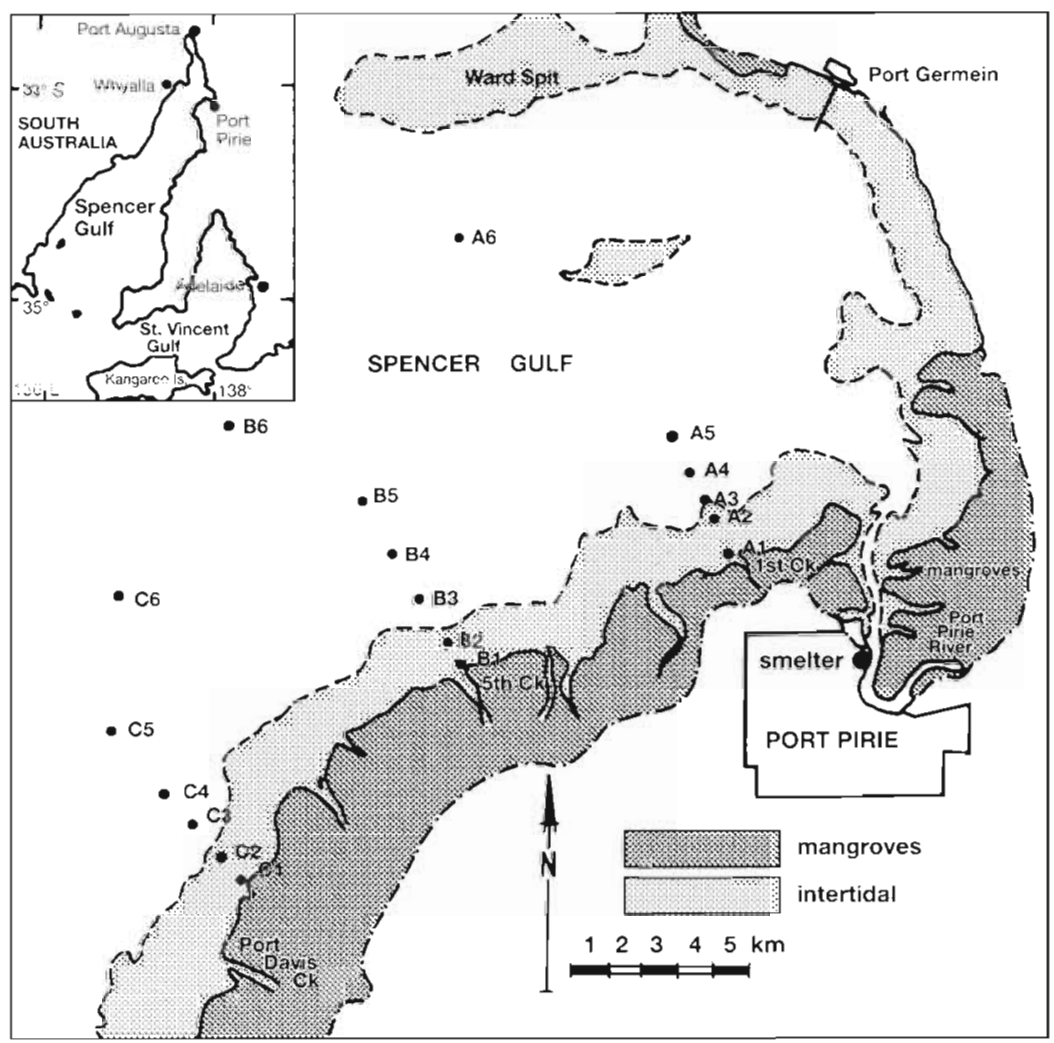

Fig. 1. The study area near the Port Pirie lead smelter, upper Spencer Gulf, South Australia, showing the sites ( 1 to 6 ) sampled on each of 3 transects (A to C) for infauna intertidal mud (Sites 1), intertidal seagrass (Zostera mucronata) (Sites 2), shallow subtidal seagrass (Posidonia australis) (Sites 3), deep subtidal seagrass (Posidonia sinuosa) (Sites 4), and 2 depths of unvegetated sediments (Sites 5 and 6). The data set thus consisted of the infauna from 9 replicates at each of 6 sites on 3 transects sampled in winter 1979 and summer 1980

The data were analysed by analysis of variance (ANOVA) and multivariate pattern analysis. The patterns of distribution in the assemblages were first determined by classification procedures. As this technique does not identify the species whose distributions are correlated to sediment trace metal concentrations, the data were also analysed by ordination. Species could then be identified by correlating their abundances to the main faunal gradients in the data, which were correlated to the metal concentrations in the sediments.

For the analysis the dataset was first reduced by excluding all species that were represented by only 1 or 2 individuals as they would be too rare to be likely to contribute significant information. This left a dataset of 233 species. One replicate sample was lost in laboratory processing, and another sample contained only the rare species and was therefore excluded. This left a total of 322 samples in the analysis.

Species richness. The species richness (total number of species per sample) in the samples was assessed by ANOVA, with transect and habitat as fixed factors and time as random. One sample was missing and this was estimated to be the mean of the other 8 samples at this site and time, and the total degrees of freedom were adjusted from 288 to 287 to compensate for the missing sample. The raw data were square-root transformed but remained heteroscedastic, by Cochran's test, so the outcome of the ANOVA was interpreted cautiously. The data set from subtidal sites was examined in the same manner.

Species composition. Classification: The multivariate statistical package PATN was used to explore the patterns in the species-site data (Belbin 1990). Raw abundance data were used for the species and sites were classified using the Bray-Curtis dissimilarity measure to generate a matrix of dissimilarities (Faith et al. 1987). Flexible UPGMA, an agglomerative hierarchical fusion program (Belbin 1990), was used to classify the sites and construct groups of sites to explore habitat differences. Initially, the sites were classified on the basis of individual replicate samples. The resulting dendrogram showed a very strong coherence 
amongst replicate samples at a site at the 18-group level. The sites were then reclassified after pooling replicates for each site at a time (reducing the $322 \mathrm{sam}$ ples to 36 samples). The 36 -sample dendrogram was very similar to the 322 -sample dendrogram at the 6 group level, again supporting a close coherence of replicates from each site at a time. Further analysis was carried out only on the 36 site-based samples with pooled replicates.

The main feature of the data was the large differences between intertidal and subtidal sites. Few species were common in both intertidal and subtidal habitats (Hutchings et al. 1993). To explore patterns in the subtidal sites, these data were reclassified using the same techniques.

Species that could be used to distinguish between the groups of sites produced by the classifications were identified by inspection of a 2-way table of species abundances in each group, and tabulated to display site differences. The 2 -way table used the Bray-Curtis classified site groups (to the 6-group level) and a classification of the species into 15 groups that used the Two Step association measure, an adaptation of the Bray Curtis measure (Belbin 1990). The complete 2way table is available from the first author.

Ordination: To examine the likely gradients in species composition, the 36-sample dissimilarity matrix was ordinated by $\mathrm{SSH}$, a nonmetric semi-strong monotonic multidimensional scaling program in PATN commonly used for ecological data (Belbin 1991).

To identify environmental correlates of the infaunal distributions the 3 vectors from the ordinations were correlated to the untransformed values of sediment data [\% total organic carbon (TOC), clay, silt, sand] taken previously from the same sites (Ward \& Young 1982). Missing values (data below the level of analytical detection) were set at half the level of detection. A dummy variable, 'habitat', with a range of 1 (shallowest) to 6 (deepest), was erected as a surrogate of habitat type because the deep unvegetated sites were not of similar depth. Species most strongly associated with the 3 ordination dimensions were determined by correlation of raw species abundances to vector scores. Significance values of all correlation coefficients ( $r$ ) were determined by Fisher's $\mathrm{r}$ to $\mathrm{z}$ transformation in the software package Statview (B) Abacus Concepts Inc.).

\section{RESULTS}

\section{Species richness}

The infauna in the study area consisted of 12396 individuals belonging to 372 taxa (Hutchings et al 1993). In the reduced dataset analysed here, the total number of taxa was 233, spread broadly across the sites sampled. The analysis of the species richness in the samples from all sites identified a 3-way interaction between habitats, times and transects and several lower-order effects (Table 1). Therefore, although samples from transects, habitats and times of sampling contained different numbers of species, these differences varied in a complex manner that could not be related directly to the effects of metals. The same was true for the species richness in samples from the subtidal sites alone (Table 1).

Table 1 ANOVA of species richness (Vtotal no. of species per sample) for taxa with total abundance $>2$ in samples from (a) all sites and (b) subtidal sites

\begin{tabular}{|c|c|c|c|c|c|}
\hline Source & df & Mean square & $F$-value & $p$-value & Error term \\
\hline \multicolumn{6}{|l|}{ (a) All sites } \\
\hline Transect & 2 & 11.201 & 35.342 & 0.0275 & Transect $\times$ Time \\
\hline Habitat & 5 & 48.016 & 4.349 & 0.0663 & Habitat $\times$ Time \\
\hline Time & 1 & 1.569 & 3.228 & 0.0728 & Residual \\
\hline Transect $\times$ Habitat & 10 & 2.051 & 1.376 & 0.3117 & Transect $\times$ Habitat $\times$ Time \\
\hline Transect $\times$ Time & 2 & 0.317 & 0.652 & 0.5203 & Residual \\
\hline Habitat $\times$ Time & 5 & 11.042 & 22.720 & 0.0001 & Residual \\
\hline Transect $\times$ Habitat $\times$ Time & 10 & 1.491 & 3.068 & 0.001 .0 & Residual \\
\hline Resıdual & 287 & 0.486 & & & \\
\hline \multicolumn{6}{|l|}{ (b) Subtidal sites } \\
\hline Transect & 2 & 4.353 & 54.123 & 0.0181 & Transect $\times$ Time \\
\hline Habitat & 3 & 12.813 & 0.706 & 0.6090 & Habitat $\times$ Time \\
\hline Time & 1 & 0.641 & 1.111 & 0.2918 & Residual \\
\hline Transect $\times$ Habitat & 6 & 1.436 & 0.752 & 0.6311 & Transect $\times$ Habitat $\times$ Time \\
\hline Transect $\times$ Time & 2 & 0.080 & 0.139 & 0.8693 & Residual \\
\hline Habitat $\times$ Time & 3 & 18.137 & 31.433 & 0.0001 & Residual \\
\hline Transect $\times$ Habitat $\times$ Time & 6 & 1.910 & 3.310 & 0.0039 & Residual \\
\hline Residual & 191 & 0.577 & & & \\
\hline
\end{tabular}


Table 2. Frequencies of species discriminating best between Site A1 and Sites B1 and C1 (intertidal bare habitat) in the classification. Abundances in each frequency class: $(-) 0$ (1) $1-162$, (2) $163-323$, (3) $324-484$, (4) $485-645$, (5) 646-806; s: data for summer; $w$ : data for winter

\begin{tabular}{|lccc|}
\hline Taxon & $\begin{array}{c}\text { Site A1 } \\
(\mathrm{s}, \mathrm{w})\end{array}$ & $\begin{array}{c}\text { Site B1 } \\
(\mathrm{s}, \mathrm{w})\end{array}$ & $\begin{array}{c}\text { Site C1 } \\
(\mathrm{s}, \mathrm{w})\end{array}$ \\
\hline Capitella 'capitata' & 1,1 &,-- &,-- \\
Tanais dulongii & 1,1 &,-- & -- \\
Neanthes vaalii &,-- & 1,1 &,-- \\
Ceratonereis sp. 1 &,-- & 1,1 & 1,2 \\
Nephtys graviern &,-- & 1,1 & 1,1 \\
Marphysa sp. 2 &,-- & 1,1 &,-- \\
\hline
\end{tabular}

\section{Species composition: classification of all sites}

Based on the data set of 233 species, the classification of all sites showed that habitat type was a dominant feature of the distribution pattern of the infauna (Figs, $2 \& 3$ ). The classification at the 6-group level revealed a structure similar to that imposed by the habitat stratification in the sampling design. Four groups contained all the intertidal sites, and 2 others contained all the subtidal sites.

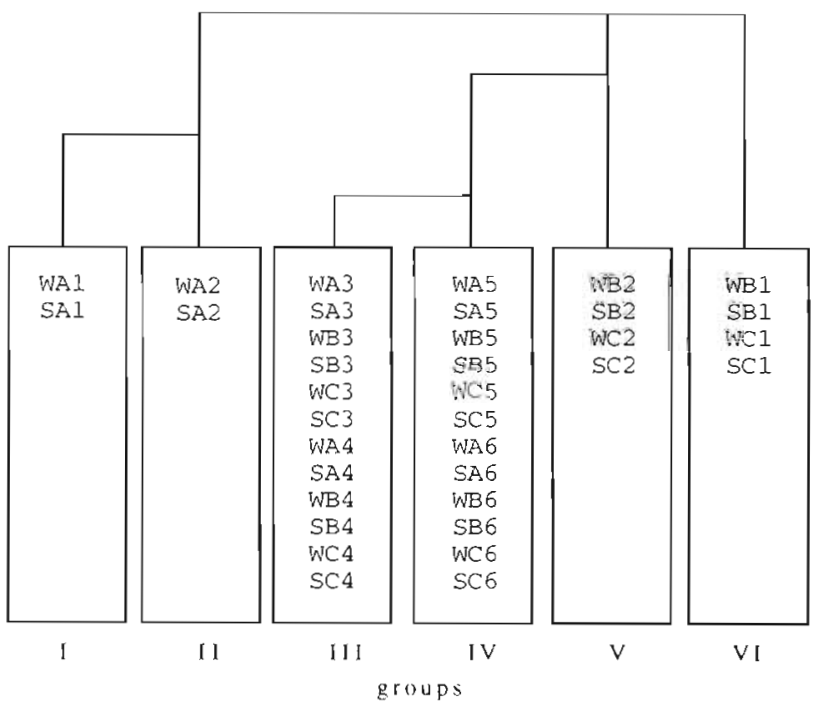

Fig. 2. Dendrogram resulting from the classification of sites based on species composition of the infauna at all sites. S: summer; W: winter; Transects A to C; Sites 1 to 6 . See Fig. 1 for location of sites and transects

The other pattern emerging from the classification of all sites was the influence of the metal contamination. The highly contaminated intertidal sites (A1 and A2) formed 2 groups that were clearly separated from the groups containing the other intertidal sites on Transects B (Sites B1 and B2) and C (Sites C1 and C2). The obvious patterns of species abundances included species presence (or absence) in the highly metal contaminated Site A1 and absence (or presence) in the less contaminated Sites B1 and C1 (Table 2). Similarly, a number of species were either present or absent from the contaminated Zostera site (A2) and present or absent from the less contaminated sites B2 and C2 (Table 3 ).

\section{Intertidal sites}

A total of 105 taxa was recorded from the intertidal sites. Of these, 42 were found at the highly contaminated sites A1 and A2 (Table 4), including 4 - the polychaetes Heteromastus filiformis, Capitella 'capitata' and Glycera americana, and the crustacean Tanais dulongii-that had very high frequencies at these 2 sites. $C$. 'capitata' and $T$. dulongii were

Fig. 3. The 6 site groups produced from the classification of all sites shown on the map of the study area 
Table 3 . Frequencies of species discrimmating best between Site A2 and Sites B2 and C2 (Zostera habitat) in the classification. Abundances in each frequency class: (-) 0, (1) 1-162, (2) $163-323$, (3) $324-484$, (4) $485-645$, (5) $646-806$; s: data for summer; w: data for winter

\begin{tabular}{|c|c|c|c|}
\hline Taxon & $\begin{array}{c}\text { Site A2 } \\
(s, w)\end{array}$ & $\begin{array}{c}\text { Site B2 } \\
(s, w)\end{array}$ & $\begin{array}{c}\text { Site C2 } \\
(s, w)\end{array}$ \\
\hline Glycera americana & 1,1 &,-- & $\rightarrow-$ \\
\hline Capitella 'capitata' & 1,4 &,-- &,-- \\
\hline Tanais dulongii & 1,5 & $-\cdots$ &,-- \\
\hline Heteromastus filiformis & 1,1 & $-{ }_{--}$ &,-- \\
\hline Macrobrachium intermedium & $-1-$ & $1,-$ & $1,-$ \\
\hline Aquilaspio multipinnula & $-1-$ & 1.1 & 1,1 \\
\hline Polycirrus tesselatus &,-- & $1,-$ & $1,-$ \\
\hline Cominella eburnea & - & $1,-$ & $1,-$ \\
\hline Euidotea bakeri &,-- & $1,-$ & $1,-$ \\
\hline Nephtys gravier & $1,-$ & 1,1 & 1,1 \\
\hline Platynereis sp. & $-{ }_{-1}^{-}$ & $1,-$ & $1,-$ \\
\hline Diplocirrus sp. &,-- & 1,1 & $1,-$ \\
\hline Sabellid sp. 1 &,-- & 1,1 & $1,-$ \\
\hline Pista violacea &,-- & 2,2 & 1.1 \\
\hline Zeacumantus diemenensis & 1,- & 1,1 & 1,1 \\
\hline Ascidiidae sp. 1 &,-- & 1,1 & $1,-$ \\
\hline Neanthes bassi &,-- &,- 1 & $1,-$ \\
\hline Sipunculan worms &,-- & $1,-$ & $1,-$ \\
\hline Pista australis &,-- & 1,1 & $1,-$ \\
\hline Cymadusa sp. &,-- & $1,-$ & $1,-$ \\
\hline Augeneria verdis &,-- & 1,1 & 1,1 \\
\hline Scoloplos simplex & $1,-$ & 1,1 & 1.1 \\
\hline Wallucina assimilis &,-- & 1,1 & 1,1 \\
\hline Brachynotus spinosus & $-1-$ & 1,1 & $1,-$ \\
\hline Katelysia rhutiphora &.-- & $1,-$ &,- 1 \\
\hline
\end{tabular}

found almost exclusively in these highly contaminated sites (Tables 2 \& 3). Conversely, 4 polychaetes (Neanthes vaalii, Ceratonereis sp. 1, Nephtys gravieri, Marphysa sp. 2) that were broadly distributed elsewhere in the intertidal sites were absent from Site A1 (Tables 2, 3 \& 4 ).

In the Zostera habitat (Sites A2, B2 and C2) 18 taxa occurred at both $\mathrm{B} 2$ and $\mathrm{C} 2$ but not at $\mathrm{A} 2$ (Table 3), the heavily contaminated site. A further 3 species were found mainly at $\mathrm{B} 2$ and $\mathrm{C} 2$, but rarely at A.2 (Table 3 ). These 21 taxa consisted of 11 polychaetes, 4 crustaceans, 4 molluscs, 1 ascidian, and sipunculan worms.

Considered together, the intertidal bare and Zostera sites in the study area contained a total of 57 species of polychaetes, 20 crustaceans and 23 molluscs. Of these, 15 species $(26 \%)$ of polychaetes, $5(20 \%)$ of crustaceans and $4(17 \%)$ of molluscs did not occur in the metal-contaminated bare (Site A1) or Zostera (Site A2) sites.

\section{Subtidal sites}

The remaining major habitat differences detected in the classification were the differences in the composi-
Table 4. Species found at the metal-polluted sites A1 and A2

Polychaetes
Glycera americana
Eteone sp. nov.
Podarke angustifrons
Ceratonereis mirabilis
Trichobranchus sp.
Neanthes sp. 1
?Scyphoproctus sp. 1
Nereis bifida
Leitoscoloplos normalls
Capitella 'capitata'
Ceratonereis sp. 1
Nephtys gravieri
Ceratonereis aequisetis
Heteromastus filiformis
Eumida sp.
Glycinde sp. 1
Phyllodoce sp. A
Armandia intermedia
Schistomeringos loveni
Mediomastus
australiensis
Cirriformia sp. 1
Cirriformia sp. 2
Caulleriella sp. 3
Caulleriella sp. 4
Notomastus sp. 1
Barantolla sp.
Scoloplos simplex
Hydroides sp 1

Molluscs

Oyster spat

Tellina deltoidalis

Laternula creccina

Zeacumantus

diemenensis

Cavatidens perplexa

Tellina mariae

Crustaceans

Ampelisca toora

Tanais dulongii

Hyale sp.

Platynympha

longicaudata

Cymodoce sp. 2

Fish

Favonigobius lateralis

Gymnapistes

ildrmoratus

Echinoderm

Leptosynapta dolabrifera

tion of species between the Posidonia habitats (Sites 3 and 4 on all transects) and the deep unvegetated habitats (Sites 5 and 6 on all transects). The pattern of species and site classifications in the 2-way table indicated that 80 species contributed to these: 45 species occurred mainly in the Posidonia and 35 species in the deep unvegetated habitats.

All 3 major taxonomic groups contributed to the differences between these 2 habitat types: 29 species of molluscs, 22 of crustaceans and 25 of polychaetes. Ten of the molluscs, 19 of the crustaceans and 14 of the polychaetes were found in the Posidonia sites but not in the deep unvegetated sites. Conversely, 19 of the molluscs, 3 relatively rare (fewer than 5 sites and times) crustaceans and 11 polychaetes were found in the deep unvegetated sites but not in the Posidonia sites.

\section{Species composition: classification of subtidal sites}

The classification of samples from only the subtidal sites showed that, at the 5-group level, the species composition at the seagrass sites (Sites 3 and 4 ) on all 3 transects was clearly different from that at the deep 


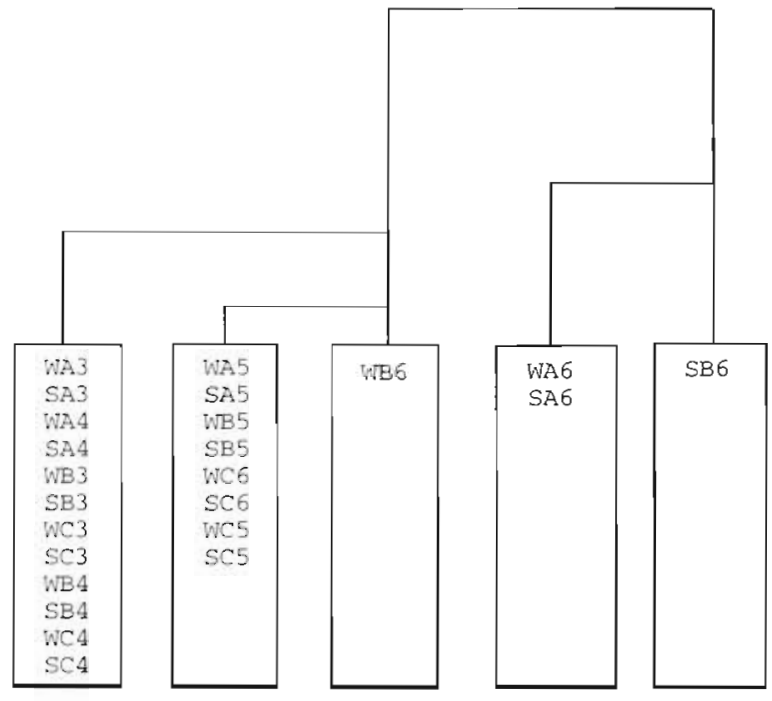

Fig. 4. Dendrogram resulting from the classification of samples from subtidal sites. S: summer; $W$ - winter; Transects A to C; Sites 3 to 6 . See Fig. 1 for location of sites and transects

Table 5. Frequencies of species discriminating best between Site A3 and Sites B 3 and C3 (Posidonia australis) in the classification. Abundances in each frequency class: $(-) 0,(1) 1-162$, (2) $163-323$, (3) $324-484$, (4) 485-645. (5) 646-806; s: data for summer; $w$ : data for winter

\begin{tabular}{|c|c|c|c|}
\hline Taxon & $\begin{array}{c}\text { Site A3 } \\
(s, w)\end{array}$ & $\begin{array}{c}\text { Site B3 } \\
(s, w)\end{array}$ & $\begin{array}{c}\text { Site C3 } \\
(5, w)\end{array}$ \\
\hline Harmothoe sp. 1 & 1,1 &,- 1 &,-- \\
\hline Neanthes kerguelensis & 1,1 &,-- &,-- \\
\hline Glycera americana & 1,1 &,-- &,-- \\
\hline Leitoscoloplos normalis & 1,1 &,- 1 &,-- \\
\hline Cirriformia sp. 1 & 1,1 &,-- & $-r^{-}$ \\
\hline Cirriformiasp. 2 & 1,1 & $1,-$ &,$-=$ \\
\hline Diplocirrus sp. & 1,1 &,-- & -1 \\
\hline Leptosynapta dolabrifera & 1,1 &,- 1 &,-- \\
\hline Ceratonereis murabilis &,-- & 1,1 & 1,1 \\
\hline Onuphid sp. 1 &,-- &,- 1 & 1,1 \\
\hline Eunice sp. 4 &,-- & 1,1 & 1,1 \\
\hline Arabella sp. 1 &,-- & 1,1 &,- 1 \\
\hline Malacoceros sp. 1 &,-- & 1,1 & 1,1 \\
\hline Petaloproctus sp. &,-- & 1,1 & 1,1 \\
\hline Lysilla pacifica &,-- & $1,-$ & 1.1 \\
\hline Polycirrus tesselatus &,-- & -1 & 1.1 \\
\hline Lanassa exelysis &.-- & $1,-$ & 1,1 \\
\hline Pista australis &,-- &,- 1 & 1,1 \\
\hline Eupolymnia koorangi &,-- & 1,1 & 1.1 \\
\hline Trichobranchus sp. &.-- & $1,-$ & 1,1 \\
\hline Stenochiton longicymba &,-- & 1,1 & 1.1 \\
\hline Apseudes australis &,-- &,- 1 & 1,1 \\
\hline Protolembos drummondae &,-- & 1,1 & 1,1 \\
\hline ?Parelasmopus sp. &,-- & $1,-$ & 1,1 \\
\hline Amphiura parviscutata &,-- & $1,-$ & 1,1 \\
\hline
\end{tabular}

unvegetated sites (Sites 5 and 6), reflecting the structural differences between these 2 habitat types. In addition, samples from both winter and summer at
Table 6 . Frequencies of species discrmminating best between Site A4 and Sites B4 and C4 (Posidonia sinuosa) in the classification. Abundances in each frequency class: $(-) 0$, (1) $1-162$, (2) $163-323$, (3) $324-484$, (4) 485-645, (5) 646-806; s: data for summer; w: data for winter

\begin{tabular}{|lccc|}
\hline Taxon & $\begin{array}{c}\text { Site A4 } \\
(\mathrm{s}, \mathrm{w})\end{array}$ & $\begin{array}{c}\text { Site B4 } \\
(\mathrm{s}, \mathrm{w})\end{array}$ & $\begin{array}{c}\text { Site C4 } \\
(\mathrm{S}, \mathrm{w})\end{array}$ \\
\hline Harmothoe sp. 1 & 1,1 &,-- &,- 1 \\
Phyllodoce sp. A & 1,1 &,- 1 &,-- \\
Nereis bifida & 1,1 &,-- &,-- 1 \\
Neanthes kerguelensis & 1,1 &,-- &,-- \\
Scoloplos simplex & 1,1 & $1,-$ &,-- \\
Leitoscoloplos normalis & 1,1 &,-- &,-- \\
Caulleriella sp. 4 & 1,1 &,- 1 &,-- \\
Diplocirrus sp. & 1,1 &,-- &,-- \\
Wallucina assimilis & 1,1 &,-- &,-- \\
Cavatidens perplexa & 1,1 &,- 1 &,-- \\
Tellina deltoidalis & 1,1 &,-- &,-- \\
Cymodoce sp. 2 & 1,1 &,- 1 &,-- \\
Amphiura parviscutata & 1,1 &,- 1 &,-- \\
Lysidice sp. 1 &,-- &,- 1 & 1,1 \\
Phylo sp. 1 &,-- &,- 1 & 1,1 \\
Scolelepis sp. 2 &,-- &,- 1 & 1,1 \\
Polycirrus tesselatus &,-- & 1,1 & 1,1 \\
Lanassa exelysis &,-- & 1,1 & 1,1 \\
Pista australis &,-- &,- 1 & 1,1 \\
Pista violacea &,-- & 1,1 & 1,1 \\
Neoleprea sp. &,-- & $1,-$ & 1,1 \\
Eupolymnia koorangi &,-- & 1,1 &,- 1 \\
Euchone variabilis &,-- & $1,-$ & 1,1 \\
Micrastrea rutidoloma &,-- & 1,1 & $1,-$ \\
Stenochiton longicymba &,-- & 1,1 & 1,1 \\
Stenochiton cf. pilsbra &,-- &,- 1 & 1,1 \\
Ischyroceridae sp. 1 &,-- & $1,-$ & 1,1 \\
Haliophasma sp. 1 &,-- &,- 1 & 1,1 \\
Scoliorhapsis sp. ?nov. &,-- & 1,1 & 1,1 \\
& & & \\
\hline
\end{tabular}

Site 6 on Transects $A$ and $B$ were distinct from those on Transect C (Fig. 4). At lower levels, the classification also distinguished between the seagrass sites on the most contaminated transect and those on the other transects. These patterns were best shown by 19 taxa of polychaetes, 3 species of crustaceans, 2 of echinoderms and 1 mollusc in the Posidonia australis habitat (Table 5), and by 18 species of polychaetes, 6 of malluscs, 3 of crustaceans and 2 of echinoderms in the $P$. sinuosa habitat (Table 6).

Although 172 taxa occurred in the deep unvegetated habitat in the study area (Hutchings et al. 1993), only 8 taxa were mainly responsible for the difference in classification between Sites A6 and B6 and Site C6: 6 polychaetes, 1 mollusc and sipunculan worms (Table 7).

\section{Species composition: ordination of all sites}

The ordination of the data from samples at all sites showed, as did the classification, that the sites were 
Table 7 Frequencies of species best discriminating between Site $\mathrm{C} 6$ and Sites $\mathrm{A} 6$ and B6 (deep unvegetated habitat) in the classification. Abundances in each frequency class: $(-) 0$, (1) $1-162$, (2) $163-323$, (3) $324-484$, (4) 485-645, (5) 646-806; s: data for summer; $w$ : data for winter

\begin{tabular}{lccc|}
\hline Taxon & $\begin{array}{c}\text { Site A6 } \\
(\mathrm{s}, \mathrm{w})\end{array}$ & $\begin{array}{c}\text { Site B6 } \\
(\mathrm{s}, \mathrm{w})\end{array}$ & $\begin{array}{c}\text { Site C6 } \\
(\mathrm{s}, \mathrm{w})\end{array}$ \\
\hline $\begin{array}{l}\text { Glycera amencana } \\
\text { Diplocirrus sp. }\end{array}$ & $1,-$ & 1,1 &,-- \\
Ceratunereis sp. 1 &,-- &,-- &,- 1 \\
Sipunculan worms & 1,1 & $1,-$ &,-- \\
Streblosoma sp. & 1,1 & 1,1 &,-- \\
Ampharetid sp. 1 &,-- &,-- & 1,1 \\
Scalibregma inflatum &,-- &,-- & 1,1 \\
Scaeoleda verconis &,-- &,-- & 1,1 \\
&,-- &,-- & 1,1 \\
\hline
\end{tabular}

Table 8. Correlation coefficients ( $\mathrm{r}$ ) between environmental parameters (from Ward \& Young 1982) and scores on the 3 ordination vectors in samples from all sites in summer and winter $(|\mathrm{r}|>0.7$ and $p<0.001)$. - indicates $|\mathrm{r}|<0.7$ and $p>0.001$

\begin{tabular}{|lcccccc|}
\hline $\begin{array}{l}\text { Para- } \\
\text { meter }\end{array}$ & \multicolumn{2}{c}{ Vector 1 } & \multicolumn{2}{c|}{ Vector 2 } & \multicolumn{2}{c|}{ Vector 3 } \\
\hline $\mathrm{As}$ & - & -0.71 & - & - & - & - \\
$\mathrm{Cu}$ & -0.83 & -0.84 & - & - & - & - \\
$\mathrm{Mn}$ & -0.86 & -0.87 & - & - & - & - \\
$\mathrm{Pb}$ & -0.83 & -0.86 & - & - & - & - \\
$\mathrm{Zn}$ & -0.83 & -0.86 & - & - & - & - \\
TOC & - & - & - & - & 0.75 & - \\
Depth & - & - & - & - & -0.84 & -0.74 \\
Habitat & - & - & - & - & -0.84 & -0.76 \\
& & & & & & \\
\hline
\end{tabular}

substantially separated by habitat type (Fig. 5). For example, subtidal sites on Transect $C$ clustered centrally on the ordination, clearly separated from the intertidal Transect $\mathrm{C}$ sites.
Ordination also clearly separated the metal-contaminated intertidal sites on Transect $A$ from the intertidal sites on Transects $B$ and $C$, which was consistent with the pattern detected by the classification.

For samples from all sites in both winter and summer the scores on Vectors 1 and 3 correlated best to the measured environmental parameters. In both summer and winter samples the scores from Vector 1 correlated well with concentrations of $\mathrm{Cu}, \mathrm{Mn}, \mathrm{Pb}$ and $\mathrm{Zn}$ in the sediments (all with $r>-0.8$ ) (Table 8), and the scores from Vector 3 correlated strongly with depth and habitat type. The scores from Vector 2 did not correlate in either winter or summer with any of the measured environmental parameters (Table 8). This confirmed that the ordination had identified and separated the 2 main environmental gradients (metal contamination and habitat type). The samples from summer and winter were similar in ordination space, relative to the other main patterns, and so temporal change was likely to be a minor factor in this data set compared to metal contamination and depth or habitat type.

To identify the species most responsible for the gradients evident in the ordination, untransformed abundances of all species were tested for correlations with the 3 vector scores (Table 9). Seven species correlated with Vector 1 ( 3 polychaetes, 2 molluscs, and 2 crustaceans) and 5 species ( 3 polychaetes, 1 mollusc and 1 crustacean) correlated with Vector 3 . These correlations suggest that these 11 species (2 species were significantly correlated to both vectors) were most obviously associated with the 2 main environmental gradients identified at all sites in the study area. Five of these species from the Zostera sites (Platynereis sp., Scoloplos simplex, Pista violacea, Zeacumantus diemenensis and Brachynotus spinosus) were identified by both classification and ordination as associated with the major gradient in metal pollution in the sediments (Tables 3 \& 7 ). In addition, 3 species of polychaetes correlated to Vector 2 although this vector was not related to any of the measured sediment or habitat factors.

\section{Species composition: ordination of subtidal sites}

The ordination of samples from the subtidal sites showed that the fauna of the sites on Transect $A$ had a consistently different composition from the fauna of sites on Transects $B$ and $C$, and that the fauna of seagrass sites was different from that of unvegetated sites (Fig. 6).
Fig. 5. Scatterplot of the scores for Vectors 1 and 3 from the ordination of the species composition dissimilarity matrix for all sites. S: summer; W: winter $r_{i}$ Transects $A$ to $C_{i}$ Sites 1 to 6 . Stress $=0.135$ 
Table 9. Correlation (r) of species frequencies to vector scores from the ordination of samples from all sites and times ( $p<$ 0.01). n: total abundance of all species in each sample

\begin{tabular}{|lrcc|}
\hline Species & Frequency & $\mathrm{r}$ & $\mathrm{p}$ \\
\hline Vector 1 & & & \\
Zeacumantus diemenensis & 6 & 0.97 & 0.0004 \\
Platynereis sp. & 5 & 0.97 & 0.0041 \\
Brachynotus spinosus & 9 & 0.80 & 0.0064 \\
Apseudes australis & 10 & 0.80 & 0.0035 \\
Scoloplos simplex & 19 & 0.70 & 0.0005 \\
Pista violacea & 16 & 0.64 & 0.0063 \\
Tellina mariae & 25 & 0.59 & 0.0014 \\
Vector 2 & & & \\
Ceratonereis sp. 1 & 26 & 0.61 & 0.0007 \\
Nephtys gravieri & 30 & 0.58 & 0.0006 \\
Cirriformia sp. 1 & 14 & -0.71 & 0.0035 \\
n & 36 & -0.58 & 0.0001 \\
Vector 3 & & & \\
Laternula creccina & 7 & 0.88 & 0.0051 \\
Apseudes australls & 10 & 0.81 & 0.0029 \\
Pista violacea & 16 & 0.68 & 0.0029 \\
Cirriformia sp. 1 & 14 & 0.67 & 0.0067 \\
Sabellid sp. 3 & 5 & -0.98 & 0.0016 \\
n & 36 & 0.52 & 0.0009 \\
\hline
\end{tabular}

The scores on Vector 2 were correlated best with the measured environmental parameters in both summer and winter (Table 10). The environmental correlates were: concentrations of $\mathrm{Cu}, \mathrm{Mn}, \mathrm{Sb}, \mathrm{Pb}$ and $\mathrm{TOC}$ in the sediments, and depth and habitat type. The concentrations of clay and the habitat type were also strongly correlated to scores on Vector 3. This suggested that the pattern of species composition in the subtidal sites detected by Vector 2 was related to the presence of the metals in the sediments. Three species of polychaetes were best associated with the Vector 2 pattern (Table 11). Of these, Caulleriella sp. 3 and Caulleriella $\mathrm{sp} .4$ occurred most often in the metal-contaminated seagrass sites. A further 5 species (Apseudes australis,

Table 10. Correlation coefficients ( $r$ ) between environmental parameters (from Ward \& Young 1.982) and scores on the 3 ordination vectors in samples from subtidal sites in summer and winter $(|\mathrm{I}|>0.7$ and $\mathrm{p}<0.001)$. - indicates $|\mathrm{r}|<0.7$ and $\mathrm{p}>0.001$

\begin{tabular}{|c|c|c|c|c|c|c|}
\hline \multirow{2}{*}{$\begin{array}{l}\text { Para- } \\
\text { meter } \\
\mathrm{Cu}\end{array}$} & \multicolumn{2}{|c|}{$\begin{array}{c}\text { Vector } 1 \\
\text { Summer Winter }\end{array}$} & \multicolumn{2}{|c|}{$\begin{array}{c}\text { Vector } 2 \\
\text { Summer Winter }\end{array}$} & \multicolumn{2}{|c|}{$\begin{array}{c}\text { Vector } 3 \\
\text { Summer Winter }\end{array}$} \\
\hline & - & - & - & 0.76 & - & - \\
\hline $\mathrm{Mn}$ & - & - & - & 0.74 & - & - \\
\hline $\mathrm{Pb}$ & - & - & - & 0.73 & - & - \\
\hline $\mathrm{Sb}$ & - & - & 0.73 & 0.77 & - & - \\
\hline Clay & - & - & - & - & - & 0.76 \\
\hline TOC & - & -0.70 & 0.74 & - & - & - \\
\hline Depth & - & - & -0.87 & - & - & - \\
\hline Habitat & - & - & -0.79 & - & 0.85 & 0.80 \\
\hline
\end{tabular}

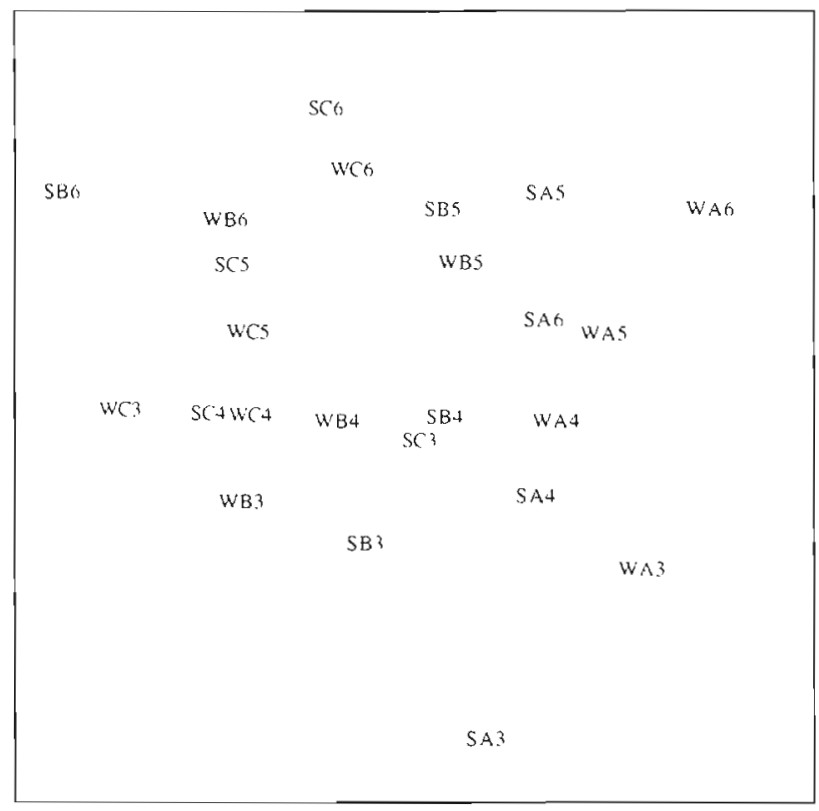

Fig. 6. Scatterplot of the scores for Vectors 2 and 3 from the ordination of the species composition dissimilarity matrix for subtidal sites. S: summer; W: winter; Transects A to $C$; Sites 1 to 6 . Stress $=0.187$

Table 11. Correlation (r) of species frequencies to vector scores from the ordination of samples from subtidal sites $(p<0.01)$

\begin{tabular}{|lccc|}
\hline Species & Frequency & r & $\mathrm{p}$ \\
\hline $\begin{array}{l}\text { Vector 1 } \\
\text { Euchone variabills }\end{array}$ & 6 & 0.96 & 0.0005 \\
$\begin{array}{l}\text { Austromytlus } \\
\quad \text { penetictus verco }\end{array}$ & 11 & 0.76 & 0.0046 \\
$\quad$ Musculus cf ulmus & 6 & 0.92 & 0.0059 \\
Vector 2 & & & \\
$\quad$ Caulleriella sp. 3 & 11 & 0.84 & 0.0006 \\
Notomastus sp. 1 & 21 & 0.61 & 0.0026 \\
Caulleriella sp. 4 & 12 & 0.74 & 0.0046 \\
Vector 3 & & & \\
$\quad$ Nephtys gravieri & 20 & 0.68 & 0.0006 \\
$\quad$ Mediomastus australiensis & 15 & -0.68 & 0.0041 \\
$\quad$ Nematonereis unicornis & 17 & -0.63 & 0.0058 \\
Eumida sp. & 10 & -0.76 & 0.0090 \\
\hline
\end{tabular}

Cirriformia sp. 1, Leptosynapta dolabrifera, Apseudes sp. 1, and Eunice sp. 3) were weakly correlated $(0.01<$ $\mathrm{p}<0.05)$ to Vector 2 .

\section{DISCUSSION}

The sediments of the intertidal and shallow subtidal areas near the lead smelter are heavily contaminated with metals, mainly $\mathrm{Cd}, \mathrm{Pb}$ and $\mathrm{Zn}$ (Ward \& Young 1982, Table 12). Their concentrations are more than an 
Table 12. Concentrations ( $\mu \mathrm{g} \mathrm{g}^{-1}$ ) of trace elements in sediments likely to have biological effects (from Long \& Morgan 1990) compared with the concentrations in sediments at the polluted sites in the study area (from Ward \& Young 1982). $E R-M$ : Effects Range minus Median

\begin{tabular}{|cccccc|}
\hline Metal & $\begin{array}{c}\text { Site A1 } \\
\text { (Bare) }\end{array}$ & $\begin{array}{c}\text { Site A2 } \\
(\text { Zostera) }\end{array}$ & $\begin{array}{c}\text { Site A3 } \\
(P \text {. australis) }\end{array}$ & $\begin{array}{c}\text { Site A4 } \\
(P . \text { sinuosa) }\end{array}$ & $\begin{array}{c}\text { Long \& Morgan } \\
(1990), \text { ER }-M\end{array}$ \\
\hline $\mathrm{As}$ & 110 & 151 & 11.5 & 9.8 & 85 \\
$\mathrm{Cd}$ & 169 & 267 & 22.5 & 9.7 & 9 \\
$\mathrm{Cu}$ & 122 & 31 & 8 & 8 & 390 \\
$\mathrm{~Pb}$ & 5270 & 2630 & 312 & 156 & 110 \\
$\mathrm{Sb}$ & 28.3 & 48.6 & 1.9 & 1.8 & 25 \\
$\mathrm{Zn}$ & 16700 & 7280 & 1300 & 631 & 270 \\
\hline
\end{tabular}

order of magnitude higher than those thought to be responsible for biological impacts elsewhere (Long \& Morgan 1990), and are amongst the highest recorded for these metals in marine sediments (Ward et al. 1984, Langston 1990). Despite this, 42 species of intauna were found living in the heavily contaminated intertidal bare and Zostera sites nearest the smelter.

Of these species, 4 were very abundant in both summer and winter at these 2 sites and appeared able to exploit the metal-contaminated conditions. They were the polychaetes Heteromastus filiformis, Capitella 'capitata' and Glycera americana, and the crustacean Tanais dulongii. $C$. 'capitata' and $T$. dulongii occurred almost exclusively in these heavily contaminated sites (mean densities of 322 and 413 ind. $\mathrm{m}^{-2}$ respectively) so the populations at these sites are probably self-sustaining. They must therefore be able to tolerate the very high concentrations of metals and exploit the available resources of food and space.

Although the remaining species recorded at the contaminated sites were probably all aduits, they might have recruited from populations outside the highly polluted area. They were also found at the other sites, and since many are likely to have planktonic larval phases, the populations in the polluted sites may not be self-sustaining in the sense that they are capable of self-maintenance in the long term.

Conversely, of the 105 species that were common in. the intertidal sites of the study area, 24 appeared to be sensitive to the effects of the metals, as they were seldom found at the heavily contaminated sites. These 15 polychaetes, 5 crustaceans and 4 molluscs represented 26,20 and $17 \%$ respectively of the intertidal taxa considered in this data set.

The flora and fauna of this study area are exposed to high concentrations of the metals. Although the concentrations of metals in the infauna of the study area have not been studied, previous studies have examined the concentrations of metals in 23 species of larger fauna (fish, crustaceans, molluscs and an ascidian) and in 3 species of seagrass (Ward et al. 1986).
Most species living closest to the smelter contained high concentrations of $\mathrm{Cd}, \mathrm{Pb}$ and $\mathrm{Zn}$, and sediments are the most likely source. Although the processes responsible for remobilising the metals from the sediments are unknown, EDTA leaching was capable of extracting 40 to $50 \%$ of the total $\mathrm{Cd}, \mathrm{Pb}$ and $\mathrm{Zn}$ from the less contaminated sediments, but 80 to $90 \%$ of the $\mathrm{Pb}$ and $\mathrm{Zn}$ and $25 \%$ of the $\mathrm{Cd}$ from the most contaminated sediments (Tiller et al. 1989). This indicates that the metals in the sediments are probably readily bio-available to all the flora and fauna living in the study area, including the infauna.

Our results suggest that there are many metal-sensitive species ( 17 to $26 \%$ of all species) in all 3 major taxonomic groups (polychaetes, molluscs and crustaceans), and that the metals do not preferentially affect any one of these groups. In contrast, a study of the Fal estuary (UK) found that metals affected meiobenthic nematodes but not benthic copepods (Somerfield et al. 1994). This difference may be related to the degree of pollution, which is lower in the Fal than in our Port Pirie study area. Rygg (1985b) found that echinoderms were sensitive to metals in Norwegian fjords. However, although we recorded 20 species of echinoderms widely distributed across the study area, their abundances did not correlate with the metals gradient so they apparently were not particularly sensitive to the metals.

It is likely that sensitive indicator species to monitor the effects of metals could be selected from either the polychaetes, molluscs or crustaceans. The apparent lack of differential sensitivity to metals amongst these groups may be related to the diversity of feeding types in each, and to the wide distribution and availability of the metals within each habitat type. Although metal concentrations in the sediments are used here as the explanatory parameters, they are also high in the water and seston near these polluted sites (Ward et al. 1984).

The polluted Zostera site had a considerably different infauna species composition from the unpolluted Zostera sites, but the composition and distribution of the seagrass appeared normal (Ward et al. 1984). This indicates that the infauna is apparently much more sensitive to the metals than is Zostera itself. Similarly, in the Posidonia meadows in this study area, the motile fauna also appears to be more sensitive to the effects of metals than the seagrass itself (Ward \& Young 1982, Ward 1987).

The tanaid crustacean Tanais dulongii was the most abundant animal recorded in this survey, but it occurred only in the contaminated intertidal sites. It is 
thought to have been introduced to Australian waters (from the ballast waters of visiting ships; Hutchings et al. 1993) and so may be a very robust species well adapted to contaminated conditions. Neither the ecological impacts of introduced tanaid crustaceans on indigenous species nor the metal-mobilising role of such robust species that exploit polluted areas is known. However, the presence of the highly abundant $T$ dulongii is likely to increase, not decrease, the availability of metals to higher trophic level consumers such as fish, which may prove to be another significant impact of species that are introduced by ships' ballast waters.

The polychaetes Capitella 'capitata' and Heteromastus filiformis are opportunistic species capable of exploiting sewage-contaminated conditions (Grassle \& Grassle 1976, Roper et al. 1989). Both are widely distributed in many marine and estuarine habitats in Australia. Our study area has no obvious nearby sources for nutrients and does not appear to be nutrientenriched: the seagrass distribution seems typical for the region (Ward et al. 1984), and no unusual algal growths were observed during sampling. However, organic carbon levels in the intertidal Zostera sites are high ( 1.9 to $5.6 \%$; Ward \& Young 1981), indicating that these sites have naturally enriched sediments. The high abundances of $C$. 'Capitata' and $H$. fillformis at these sites indicates that they can exploit enriched conditions that are also highly polluted with metals.

Laboratory studies suggest that the effects of sediment metals on Capitella capitata are related to the sulfide-binding capacity in the sediments (Casas \& Crecelius 1994). Although the concentrations of $\mathrm{Zn}$ in the sediments of our study area approach toxic levels for C. capitata (Casas \& Crecelius 1994), populations of C. 'Capitata' appear to be self-sustaining. It is unlikely that their resistance is related to the sulfide levels in the sediments because, although most of the metals in the sediments are in forms closely associated with sulfide (Ward et al. 1984), the sulfide binding process would probably not selectively protect only some species of the infauna. As the sulfide forms of the metals are readily extracted from the sediments by weak acid (Ward et al. 1984), the metals may be mobilised in the long term through direct ingestion of sediment particles by scavengers and filter-feeders. The sulfide binding of the metals may therefore protect the infauna in the short term (and protect it from acute toxicity), but it is unlikely to provide long-term protection of the fauna from the effects of metals. The resistance we have seen here in C. 'capitata' and other polychaete species is more likely to be related to species-specific factors than to chemical factors such as sulfide-binding processes in the sediments.

In the subtidal seagrass sites, although the metals appeared to have clear effects on the infauna assem- blage (Fig 6), few species could be identified as having a pattern of distribution correlated to the gradient in metals. Two species of Caulleriella had increased frequencies (so were apparently advantaged by the metal-contaminated conditions), while 2 species of the crustacean genus Apseudes had very low abundances in the polluted Posidonia australis site (so were apparently disadvantaged). The concentrations of $\mathrm{Cd}, \mathrm{Pb}$ and $\mathrm{Zn}$ at the polluted $P$. australis site are above the levels suggested as likely to have biological effects, and $\mathrm{Zn}$ is even higher in the $P$. sinuosa site (Table 12 ; Long \& Morgan 1990). However, detection of the effects of the metals in the subtidal seagrass sites is confounded by the gradient in sediment TOC, which also correlates with the faunal pattern. To separate them, an intensive faunal sampling program with finer resolution of the metal gradient would be necessary.

The species composition of the infauna in the summer and winter could not be separated by the analysis. Any differences were apparently smaller than the differences in species composition detected amongst habitat types and amongst metal-contaminated sites. However, the lack of a detected difference may have been because the $2 \mathrm{~mm}$ mesh used in the sampling would not have effectively sampled juveniles and new recruits.

The analysis of the total number of species did not identify any consistent interpretable links between habitats, transects and times. The number of species of infauna is not, therefore, a sensitive parameter for studying the effects of the metals in this study area, or assessing the effects of improved management practices such as reducing effluent concentrations or metal loads. As with other simple species indices (Gray et al. 1990), there may be no apparent effect until the concentrations of metals far exceed those measured in even the most polluted marine systems.

For future studies examining the recovery of the infauna in response to reduced metal input from the smelter (and the natural burial of older sediments), the 7 species best correlated to Vector 1 in the ordination of all samples (Table 9) would be the most suitable indicator species. The correlations of other species. such as the capitellids and the cirratulids, are confounded by the influences of high TOC concentrations in the sediments. Also, there are few data from other studies that could support a model that used shrinking populations of these species to document the recovery of sites from metal pollution. It is more likely that reducing the toxicity would permit the sensitive species to recolonise the presently affected areas.

The proposed indicator species (Table 9), which are all less abundant in the metal-contaminated sites, occur naturally in a variety of subtidal and intertidal seagrass sites, and in sufficient numbers to enable a 
cost-effective and statistically powerful sampling program to be designed. The 3 polychaetes, 2 molluscs and 2 crustaceans have different modes of feeding and different natural histories. They could be used to monitor the recovery of this area if the concentrations of the metals in the sediments are reduced, and measuring these species would probably be the most effective strategy to document recovery of the polluted sites.

Future studies in this area should examine the extent to which populations at the polluted sites sampled in this study are stable and self-sustaining. Whilst the polluted sites have a significant (and surprisingly high) diversity and abundance of infauna, the extent to which this is maintained by recruitment from parent populations in unpolluted areas is not known. Studies of Capitella species suggest they can quickly recolonise suitable substrates after pulse disturbance without recruiting from distant populations (Tsutsumi 1990), but there are few data on whether infaunal species can maintain their abundance when disturbances are continuous, such as those of sediment metals. If the species living in the polluted sediments are largely self-sustaining and not dependent on recruits from less (or non-) polluted areas, it will be important to determine the extent to which the populations of fauna living in these sediments are genetically adapted to highmetal conditions. If such populations have adapted over the more than a century of pollution near Port Pirie, the relevance of laboratory-derived models for predicting ecological effects of metals in this area, and possibly others, is questionable.

The degree to which our conclusions about the ecological effects of the metals can be extrapolated to other sites depends on the similarity of the sites; the physical transport of water and sediments, the chemical and physical properties of the sediment itself, and the life histories of the fauna concerned are all likely to influence the response of infauna assemblages to metal pollution. Unless the properties of these sites are similar, the ecological effects of the concentrations of metals in the sediment may not be the same. For example, in a more enclosed bay, where the tidal and winddriven currents are slower, fauna might not recruit from distant parent populations, so the effects of metals would be considerably more severe than was observed near the Port Pirie lead smelter

Acknowledgements. The field work for this study was financially supported by the International Lead Zinc Research Organization, New York, NY, USA. We are grateful to the CSIRO Division of Soils for the use of laboratones, and to Dr K. Tiller for his advice, encouragement and support. Samples were collected and sorted with the assistance of V. Neverauskas and numerous field and laboratory staff. Taxa were identified by staff of the Australian Museum particularly J. Waterhouse, I. Lock, H. Stoddard, R. Spnngthorpe and L.
Walker. The data were analysed with the help of M. Vanderklift and C. Jacoby (CSIRO Division of Fisheries). We thank C. Jacoby and S Rainer (CSIRO Division of Fisheries) for their comments on the draft manuscript.

\section{LITERATURE CITED}

ANZECC (1992) Australian water quality guidelines for fresh and manne waters. Australian and New Zealand Environment and Conservation Council, Canberra

Belbin L (1990) PATN pattern analysis package, technical manual. CSIRO Division of Wildlife and Ecology, Canberra

Belbin L (1991) Semi-strong Hybrid Scaling, a new ordination algorithm. J Veg Sci 2:491-496

Casas AM, Crecelius EA (1994) Relationship between acid volatile sulfide and the toxicity of zinc, lead and copper in marine sediments. Environ Toxicol Chem 13:529-536

Faith DP, Minchin PR, Belbin L (1987) Compositional dissimilarity as a robust measure of ecological distance. Vegetatio 69:57-68

Grassle JP, Grassle JF (1976) Sibling species in the marine pollution indicator Capitella (Polychaeta). Science 192 : $567-569$

Gray JS, Clarke KR, Warwick RM, Hobbs G (1990) Detection of initial effects of pollution on marine benthos: an example from the Ekofisk and Eldfisk oilfields, North Sea. Mar Ecol Prog Ser 66:285-299

Hutchings PA, Jacoby CA (1994) Temporal and spatial patterns in the distribution of infaunal Polychaetes in Jervis Bay, New South Wales, Australia. In: Dauvin JC, Laubier L, Reish DJ (eds) Actes de la 4ème Conférence internationale des Polychètes. Mem Mus Nat Hist Nat, Paris $162: 441-452$

Hutchings PA, Ward TJ, Waterhouse J, Walker L (1993) Infauna of marine sediments and seagrass beds of Upper Spencer Gulf near Port Pirie, South Australia. Trans Roy Soc South Aust 117:1-15

Langston WJ (1990) Toxic effects of metals and the incidence of metal pollution in marine ecosystems. In: Furness RW Rainbow PS (eds) Heavy metals in the marine environment. CRC Press, Boca Raton, p 101-122

Long ER, Morgan LG (1990) Potential for biological effects of sed.ment-sorbed contaminants tested in the National Status and Trends Program. Rep NOAA/TM/NOS/OMA-52. NOAA, Seattle

Luoma SN (1990) Processes affecting metal concentrations in estuarine and coastal marine sediments. In: Furness RW, Rainbow PS (eds) Heavy metals in the marine environment. CRC Press, Boca Raton, p 51-66

Roper DS, Smith DG, Read GB (1989) Benthos associated with two New Zealand coastal outfalls. NZ J Mar Freshwat Res 23:295-309

Rygg B (1985a) Effect of sediment copper on benthic fauna. Mar Ecol Prog Ser 25:83-89

Rygg B (1985b) Distribution of species along pollutioninduced diversity gradients in benthic communities in Norwegian fjords. Mar Pollut Bull 16:469-474

Somerfield PJ, Gee JM, Warwick RM (1994) Soft sediment meiofaunal community structure in relation to a long-term heavy metal gradient in the Fal estuary system. Mar Ecol Prog Ser 105:79-88

Tiller KG, Merry RH, Zarcinas B, Ward TJ (1989) Regional geochemistry of metal-contaminated surficial sediments and seagrasses in upper Spencer Gulf, South Australia. Estuar Coast Shelf Sci 28:473-493 
Tsutsumi H (1990) Population persistence of Capitella sp (Polychaeta; Capitellidae) on a mud flat subject to environmental disturbance by organic enrichment. Mar Ecol Prog Ser 63:147-156

Ward TJ (1987) Temporal variation of metals in the seagrass Posidonia australis and its potential as a sentinel accumulator near a lead smelter. Mar Biol 95:315-321

Ward TJ, Correll RL (1992) Estimating background concentrations of heavy metals in the marine environment. In: Miskiewicz AG (ed) Proceedings of a bioaccumulation workshop: assessment of the distribution, impacts and bloaccumulation of contaminants in aquatic environments. Sydney Water Board and Australian Marine Sciences Association Inc, Sydney, p 133-139

Ward TJ, Correll RL, Anderson RB (1986) Distribution of cadmium, lead and zinc amongst the marine sediments, seagrasses and fauna, and the selection of sentinel accumula-

This artıcle was submitted to the editor tors, near a lead smelter in South Australia. Aus J Mar Freshwat Res 37:567-585

Ward TJ, Jacoby CA (1992) A strategy for assessment and management of marine ecosystems: baseline and monitoring studies in Jervis Bay, a temperate Australian embayment. Mar Pollut Bull 25:163-171

Ward TJ, Warren LJ, Tiller KG (1984) The distribution and effects of metals in the marine environment near a lead-zinc smelter, South Australia. In: Nriagu JO (ed) Environmental impacts of smelters. John Wiley and Sons, New York, p 1-73

Ward TJ, Young PC (1981) Trace metal contamination of shal low marıne sediments near a lead smelter, Spencer Gulf, South Australia. Aus J Mar Freshwat Res 32:45-56

Ward TJ, Young PC (1982) Effects of sediment trace metals and particle size on the community structure of epibenthic seagrass fauna near a lead smelter, South Australia. Mar Ecol Prog Ser 9:136-146

Manuscript first received: March 24, 1995

Revised version accepted: December 11, 1995 